\title{
Sultan ve Foucault: II. Abdülhamid Döneminde Cuma Selamlığı, Arz-ı Hâller ve İktidarın Mikrofiziğinde "Güç Aşındırmaları" (1876-1908)
}

\author{
Cem Doğan ${ }^{1}$
}

Özet: Geleneksel Ortadoğu siyaset üslubunun yüzlerce yıl kabul gören ayırıcı yönü, halkın mustarip bulunduğu bir konu hakkında gerek bireysel gerekse çoğul biçimde şikâyetlerini yönetim katına ulaştırabilmesi olmuştur. Böylece, bir yandan padişah ve çevresindekiler halkın yakınmalarını göz önünde bulundurabilmişler, diğer yandan da halk gerektiğinde küçük bir pusula kaleme alarak yetkililere teslim etmek suretiyle derdini padişaha aktarabilmiştir. Dahası, Osmanlı'daki temel devlet kurumlarından biri olarak hizmet veren Divân-1 Hümâyûn'un aslî görevi halktan gelen şikâyet ve önerileri doğrudan padişahın huzurunda tartışmaya açmaktı. Osmanlı şikâyet mekanizmasının en fonksiyonel taraflarından biri ise Cuma Selamlığı idi. Burada, halk arz-1 hâl veya rikā', ruk'a, mahzar, kâğıt ve son dönemlerde bazen arîza adı verilen maruzat pusulalarıyla padişahtan beklentilerini dile getirirdi. Bu, padişahın reaya üzerindeki otoritesini pekiştirmenin de bir yoluydu. Zira bu dilekçelerin sık sık toplanması bir padişahın halkıyla ne kadar ilgilendiğinin, onları ne kadar önemsediğinin de sembolü oluyordu. Arz-1 hâller hem en başından beri aracı bir bürokrasinin padişah-halk ilişkisinin nabzını tutmasına zemin hazırlamış hem de politik gücün aşındırılması ve sürekli olarak yeniden üretilmesi anlamında halkı iktidarın zenginliği ve gözetimine bir kertede ortak etmiştir. Bu çalışma, II. Abdülhamid (1876-1908) döneminde halk tarafından padişaha sunulan maruzatları ve bu arzların idarî sistem açısından önemiyle bir iktidar pratiği olarak nasıl işlevselleştiğini göstermeyi amaçlamaktadır.

Anahtar Kelimeler: Osmanlı Devleti, II. Abdülhamid, M. Foucault, İktidar, Arz-1 Hâl, Güç Aşındırması

\section{Sultan and Foucault: The Friday Parade, Petitions, and "Power Corrosions" in the Microphysics of Puissance in the Reign of Abdülhamid II (1876-1908)}

Abstract: The distinctive aspect of the traditional Middle Eastern political style, which has been accepted for hundreds of years, has been that it can convey the complaints of the people to the management level both individually and in plural form. Thus, on the one hand, the sultan and his entourage were able to take into account the complaints of the people, and, on the other hand, the people were able to convey their troubles to the sultan by writing a small compass when necessary and delivering it to the authorities. Moreover, the main duty of the Divân-1 Hümâyûn, which served as one of the basic state institutions in the Ottoman Empire, is to open the complaints and suggestions from the public directly before the sultan. The area where the Ottoman grievance mechanism worked most frequently was the Friday Parade. Here, they expressed their expectations from the sultan with their exposure called arz-ı hâl or rik' $a$. This was also a way of consolidating the sultan's authority over his subjects. Because the frequent collection of these petitions was a symbol of how much a sultan was interested in his people and how much he cared for them. From the very beginning, the states of supply paved the way for an intermediary bureaucracy to keep the pulse of the relations between the sultan and his subjects, and in the sense of the abrasion and continuous reproduction of political power, they shared wealth and surveillance of the government with the people up to a point. This study aims to show the petitions presented to the sultan by the people during the reign of Sultan Abdülhamid II (1876-1908) and how these supplies functioned as a power practice with their importance in terms of the administrative system.

Keywords: Ottoman Empire, Abdulhamid II, M. Foucault, Power, Petition, Corrosions of Power

${ }^{1}$ Ĭğdır Üniversitesi, Tarih Bölümü, Iğdır, Türkiye, dogancem1 @ hotmail.com, ORCID ID: 0000-0002-2008-3830

Received: 18 January 2021, Accepted: 10 March 2021, Online: 30 April 2021

* Corresponding Author 


\section{Giriş}

Osmanlı Devleti nevi şahsına münhasır bir kamu örgütlenmesine ve bu bağlamda da uzunca bir süre işlevselliğini korumayı başaran geniş bir bürokratik ağa sahipti. Osmanlı Devleti, idarî örgütlenme ve buna bağlı merkez teşkilatı açısından İslamiyet'ten önceki Türk devletleri ile İslamiyet'in kabulünden sonra kurulan Müslüman Türk devletlerin birikimlerinden çıkarsanan başarılı bir sentezi temsil ediyordu. Bu bağlamda, Osmanlı Devleti, kendisinden önceki Türk devletlerinin siyasî, idarî, askerî ve sosyal alanlardaki kültür mirasını da devralmıştır. Osmanlılar, özellikle mirasçısı olduğunu iddia ettikleri Türk-İslam devleti olan Anadolu Selçuklularına ait yönetsel dizgeyi örnek alarak geliştirmeyi ve bunları günün gereklerine uygun düşecek pratik bir potada eritmeyi başarmıştır.

Kanuni Sultan Süleyman (h. 1520-1566) döneminin nihayetine dek oldukça bütüncül ve merkezi bir yapı arz eden bu bürokratik aygıt, toplumsal uzamda genel olarak iki sınıfı temsil ediyordu. Halil İnalcık'ın da belirttiği gibi, bunlardan ilki yönetilenler kitlesini oluşturan reaya, ikincisi ise yönetme erkini iyeliğinde bulunduran askeri sınıf idi. Genel olarak bakıldığında, ilk sınıfın salt askerleri içermediği, bilakis bütün devlet memurlarını ve hatta ailelerini de kapsayan geniş bir bloğu temsil ettiği görülüyordu (İnalcık, 2019, s. 453). Bu sistemde, politik güç toplumu teşkil eden tüm sınıflardan açıkça ayrıştırılmıştı. Köylüler, zanaatkârlar ve tüccarlar havâss adı verilen seçkinler dairesinin dışında bırakılmıştı. Devletin ihdasında yalnızca geniş halk kitlelerinin değil, seçkinlerin bile yasal olarak tanımlanmış herhangi bir pozisyonları mevcut değildi ve bunların statüleri gelenekten beslenmekteydi (Berkes, 1964, s. 16).

Osmanlı bürokratik aygıtının en belirgin niteliği merkez ile çevre arasındaki mesafede tecessüm ediyordu. Merkezin çevresel etkilere kapalı olması, merkezi otoritenin dayandığı özgül örgütlenmenin de ana kaynağıydı. Periferiyi oluşturan unsurların merkezden bağımsız hareketine elverişli bir alan ve Batı Avrupa toplumlarında görüldüğü gibi mülkiyet hakkına sahip bir sivil toplum anlayışı gelişmemişti. Osmanlı bürokrasisinin köklerine içkin prensipler müşterek toplumsal değerlerden ve kültürel dinamiklerden kaynaklanmakla birlikte kendine özgü normlarla şekilleniyordu. Bu nedenle de devlet-toplum ilişkileri bir "sözleşme" ya da "uzlaşma"dan ziyade devletin topluma baskın gelmesi esasına dayanmaktaydı (Çaha, 1994, s. 83). Geçmişte yaratılan merkeziyetçi muhkem imaj, devletin 17. yüzyılın sonlarından itibaren almaya başladığı yenilgileri büyük ölçüde perdeledi. Bu ise yetkililerin devlet katında olduğu gibi toplumdaki yozlaşmayı görmelerine engel oldu (Akyıldız, 2018, s. 18).

Yine de, sivil toplum üyelerinin iktidarla olan münasebetlerini düzenleyen birtakım pratikler her zaman var olmuştu. Bunlardan biri, aşağıda değinileceği üzere, cuma selamlığında ahali tarafından yetkililere 
ulaştırılan arz-1 hâllerdi ${ }^{1}$. Merkezi güçten pay alamamış olsalar da avam halkın bu gücü yönlendirme kabiliyetini saklı tutan arz-1 hâller, halk için bir bakıma katı yönetsel parametrelerce tespit edilen iktidar alanına dâhil olmanın başat yolu idi. Diğger bir ifadeyle, arz-1 hâller devletle toplumu müşterek bir platformda buluşturuyor, halkın isteklerinin devletin imgesel kulağına ulaşmasında aracılık rolünü üstleniyor ve bir bakıma talepleriyle gücü hem tahkim ediyor hem de elde edebildikleriyle onu aşındırıyordu.

\section{Foucault Faktörü ve İktidarın Mikrofiziği: Gücü Kurmak}

Yönetim sistemi ister demokratik ister otokratik olsun devlet her zaman yönetsel amaç ve faaliyetleri yerine getirebilmek için bürokratik bir örgütlenmeye ihtiyaç duymuştur. Hatta bürokrasinin tarihsel gelişimine bakıldığında, bu kavramın toplum adına yapılması gerekenler için kurulmuş olan devletten daha önce tarih sahnesinde yerini aldığı görülür (Akçakaya, 2016, s. 275). Osmanlı yönetici sınıfını oluşturan diğer gruplar gibi (Ulema hariç), bürokrasinin üyeleri de kul kökenliydi; bir başka deyişle, bürokrasi ile toplumsal gruplar arasında herhangi bir organik bağ bulunmuyordu. Bu durum, bürokratların padişaha kişisel bağlılıklarını sağlayan önemli bir faktördü. Bunun yanında, bürokratların Enderun'da gördükleri eğitim söz konusu bağlılığı pekiştirici bir fonksiyon icra etmekteydi (Aslan ve Yılmaz, 2001, s. 289).

Şerif Mardin'in (1990, s. 181) de altını çizdiği gibi, Osmanlıların "nizâm-1 âlemci” tutumunda uyruklar, yani teba araçsal bir öneme sahipti. Buna göre, uyrukları hoş tutmak esastı ve devletin işlevlerini eksiksiz biçimde yerine getirebilmesi de bu koşulun sağlanmasına dayanıyordu. Ne var ki, bu prensibin merkez noktasında devlet yer alıyordu, uyruklar değil. İlkesel olarak bu algının karşıtını benimseyen tutum ise ancak Tanzimat döneminde belirmeye başlamıştı. Döneme ilişkin daha derinlikli bir analiz geliştirmekte Michel Foucault'nun “devlet aklı” mefhumu kilit bir rol üstlenebilir. Foucault, yönetimsel aklın, nasıl bir düşünme, akıl yürütme ve hesaplama biçimine yol açtığını göstermeye çalışmıştır. Devlet aklının pastorallikten farkını ve 17. yüzyıldaki devlet aklı sorununu; darbe ve şiddet, itaat ve başkaldırı, hakikat sorununun aldığı yeni biçim, istatistik ve nüfus konuları bağlamında ele almıştır. Buna göre, devlet aklının devletten başka hiçbir ereği yoktu. İnsanlara devletin dışında hiçbir şey vaat etmeyen bu yapının zihinsel işleyişi de ortaya bir köken ya da nihai durum koymuyor, bilakis insanları ucu açık bir tarihselliğin içine hapsediyordu (Gölbaşı, 2015, s. 334).

Hakikaten, devlet aygıtını idare edenler, yani politik gücü elinde bulunduranlar açısından iktidarın kendisi devletin hem nedeni hem de sonucudur. Devlet kendi varoluşsal bekası için devlettir ve bunun

\footnotetext{
${ }^{1}$ Sadece Cuma selamlığı sırasında değil Dîvân-1 Hümâyun, ikindi divanı, cuma divanı ve taşradaki eyalet divanları gibi en yetkili idarî organların başlıca görevleri arasında da arzuhalleri kabul etmek ve değerlendirmek mevcuttu. Lakin burada gerçekleştirilecek tartışma bağlamında konu yalnızca Cuma selamlığı uygulamasıyla sınırlı tutulmuştur (y.n.).
} 
istisnası pek azdır. Klasik tanımlardan yola çıkan Foucault, devlet aklını karakterize eden başlıca hususları sıralamıştır. Ona göre, en başta belirtilmesi gereken nokta, devlet aklı tanımının içerisinde hiçbir şeyin devletten başka bir şeye göndermede bulunmadığıdır. İkincisi, devlet aklının devletin bizzat özü olmasıdır ve bu, yönetimin temel dayanaklarından birini simgeleyen bir sanattır. Üçüncü olarak, devlet aklı muhafazakârdır çünkü bu tahayyüle içkin temel kaygı devleti muhafaza etmenin devamlılığından kaynaklanır (Foucault, 2013, s. 224).

Foucaultyen deyimle konuşursak, bir 'stratejiler ă̆ı' olan iktidar konumlarının “bilme” edimi üzerinden etki alanlarına dâhil ettikleri kurumsal yapılara ve kişiler üstü bir görünüme sahip toplumsal değerlere olan içkinlikleri, iktidarın, uzamını toplumsalın her pikseline yaymasına ve adeta cismanî bir şekle bürünmesine yol açar. Bunun iki sonucu vardır. İlki, iktidarın ördüğü ilişkisel çemberin periferisinde yer alan bireyin, bu haliyle bir tür iktidar nesnesine dönüşmesi ve iktidar erkinin siyasal pratiklerle bağlı olduğu alanları aşarak kendini toplumsal düzlemde bir kimlik olarak tesis etmesidir. İkincisi ise iktidar mekanizmalarının toplumsala yönelik uygulama ve söylemleriyle kendini bireylere tek tek ama aynı zamanda bütüncül olarak kabul ettirmesi ve ikna süreçleriyle öngörülen zaman ve mekânlarda, bir yandan iktidar öznesi olarak kurulurken aynı zamanda toplumsal hegemonyanın üretildiği süreçler açısından bir nesne olarak tanımlanmasının yolunu açmasıdır.

Böylelikle, gücün kendisinden mütemadiyen aşırıldığı ve tekrar bahşedildiği iktidar nesneleri hem itaatle hem de tahakkümü perdeleyen rıza mefhumuyla ilişkili kılınırlar. Birbirinin artbileşeni olan bu sosyo-kültürel iktidar pratikleri, özne ile nesne uyuşmazlığı noktasında kalıtsal bir müzakere süreci inşa ederek öznelik-nesnelik fenomenlerinin iktidar mekanizmasının kurumsal ve toplumsal uzanımlarıyla girift bir yapı oluşturmasına yol açar. Bu, iktidarın nesneye kendini dayatması değil, bilakis bireyle iktidar uzamı arasında yer alan boşluğun doldurulması ve nesne-iktidar dikotomisi üzerinden iktidarla bireyin yekvücut kılınmasıdır. Bu birleşim işlemi, nesnenin iktidara ilişkin edim ve söylemlerinin yetke üretim süreçleri üzerinde yol açabileceği olası etkilerin öngörülmesini mümkün kılar.

İktidarın, toplumsal yaşantıda bireyleri değişken kimlik kategorileri üzerinden kurguladığı kadar kişi öbeklerinin tutumları karşısında kendini de toplumsalın içinde sürekli yeniden konumlandıran bir anlamsal ilişkiler bütününü temsil etmesi, kendisine nesne olan öğeler üzerinde kurguladığı tahakküm ilişkilerinin üzerini, iktidar pratiklerine meşruiyet zemini hazırlayan bir söylemler bütünü içerisinde görünmez kılar. İktidar imlemlerinin, karakteristik toplumsal ‘çok'lukları tekilleştiren içsel yapısıyla insanî edimler üzerinde tesis ettikleri meçhul ama bir o kadar özdeksel otorite nosyonu, iktidarın özdeğini teşkil eden bireyin, üzerinde kurulan muhayyel tahakküme direnme kapasitesiyle sınırlılık kazanır. 
"İktidarın olduğu yerde”, der Foucault (1978, s. 95), “direnç de vardır ama bu direnç hiçbir zaman iktidara dışsal bir konumda değildir”. Hiç şüphesiz, Foucault tahakkümü dengeli ve asimetrik güç ilişkileri sistemleriyle tanımlayan ilk kişi değildir. Bununla birlikte, onun tanımı bu tür sistemlerin her zaman güç özneleri arasındaki birincil bir ilişki alanı içinde elde edilen veya dayatılan ikincil sonuçlar olduğunu belirtmesi bakımından anlamlıdır (Patton, 1994, s. 66). Bu bireysel direnç çoğu zaman iktidarın kişiyi bir tehdit unsuru olarak algılamasına ve gündelik pratikler üzerinde sahip olduğu düzenleme yetkisinden aldığ hükmetme kudretiyle onu yeniden tanımlayarak iktidar süreçlerinden hem dışlamasına hem de onu bu süreçlere dolaylı olarak ortak kılmasına neden olur. Bu bağlamda, post-endüstriyel toplumlar, iktidarın tesis edilmesi ve dağıtılması bağlamlarında özel bir öneme sahiptir. Gerçekten de, endüstri sonrası iktidar anlayışının üretim ilişkileri dizgesi ve sınıfsal sömürü araçları aracılığıyla yeniden şekillenmesinin toplumsal uzamda çizdiği yeni sınırlar, iktidarın nesnesini oluşturan bireyin artık tek bir yönetici ile muhatap olmaktan çıkmasına ve daha karmaşık iktidar süreçlerinin bir parçası kılınmasına yol açmıştır.

\section{Osmanlı’da Cuma Selamlığı ve Sembolik Güç İlişkileri}

Bir toplumu yönetenlerle o toplumun üyeleri arasında bağlantı kurmanın muhtelif yolları vardır. $\mathrm{Bu}$ açıdan, tarih boyunca gerek yönetim katından gelen talepler gerekse halkın benimsediği birtakım uygulamalarla söz konusu iletişim sağlanmıştır. Osmanlı padişahları da bu türden bir diyaloğun tesisi için çeşitli törenleri araçsallaştırmışlardır. Osmanlı kamusal alanı padişahın şahsında ve sarayı merkeze alan uygulamalar ile biçimlendirilirken pek çok unsur onu görünür kılmıştır. Bunlardan en etkin olanları törenler, basında çıkarılan haberler, kamu yatırımları ve hayır işleri olarak sıralandığında aslında hepsinin girift bir blok oluşturduğu görülür (Demirel, 2019, s. 95).

Cuma selamlığı, padişahların Cuma namazlarını eda etmek amacıyla saray dışında bir camiye gidişdönüşlerini ve bu esnadaki merasimleri ifade ediyordu. Sultan ve tebaasının arasındaki mesafenin muhafaza edilmesi İslam monarşilerinin müşterek niteliklerinden biriydi. Fakat 11. yüzyılda Selçuklu Sultanı Melikşah'a vezirlik eden Nizamü'l-mülk'ün bu alandaki pratik formülasyonlarına Pers siyaset geleneğinden aktarılan birtakım prensiplerin uygulanmasıyla ortaya İslami bir sentez çıkmıştı. Bu sentezin temel önermesi, sultanın haftada en az iki kez halkın arasına karışarak onların hallerini ve şikâyetlerini birinci ağızdan işitmesinin önemine vurgu yapıyordu. Bu düşüncenin reel manada ortaya çıkışı cuma selamlığı ile oldu (Alikılıç, 2004, s. 100). 
Belirtildiği gibi, cuma selamlığı geleneği İslam devletlerinde alışılagelmiş bir uygulamaydı ama İslamİran devlet teşrifatını kendine özgü biçimde geliştiren Osmanlı Devleti bunu bir adım öteye taşımıştı. Dini vecibelerinden biri olarak cuma namazını kılmaya giden padişah böylece halktan kopuk olmadığını, bilakis onlarla birlikte yaşadığını göstermiş oluyordu. Zira dini ve siyasi yönü olan selâmlıklar halkın şikayetlerini doğrudan padişaha arz etmesinin en önemli yollarından birisiydi (İpşirli, 1991, s. 464). Cuma selâmlığı mahreç almadan evvel "sarık alayı" düzenleniyordu. Bu alayda bir Enderun ekibi hazır bulunup padişahın sorguçlu sarığını, saraydan o gün namaz kılacağı camiye götürüyordu. Bu usûl cuma selâmlığının hangi camide yapılacağını halka önceden bildirmenin bir yoluydu (Sakaoğlu, 1995, s. 112).

"Cuma alayı", "selamlık resmi" ya da "selamlık resm-i âlîsi" adıyla da anılan bu seremoni, Osmanlı Devleti'nde padişah-halk ilişkilerini anlamlandırmak bakımından son derece önemli bir pratikti. Zira cuma selamlığının en büyük toplumsal işlevlerinden bir tanesi halkın padişaha ulaşabilmesini sağlamasıydı. Böylece padişah halkın nabzını yoklayabiliyordu (Aykurt, 2001, s. 201). Uriel Heyd'in (1973 , s. 227-228) de belirttiği gibi, padişahın, yanlışları gideren bir adalet mekanizması işlevinin bulunduğu yolundaki geleneksel kanı, Müslüman olsun ya da olmasın, uyrukluğunda bulunan her bireyin ona arz-1 hâl edebilmesinin yolunu açıyordu. Bu türden ricaların en pitoresk ve dramatik olanıysa padişahın cuma namazına ya da ava gidişi sırasında kendisine arz edilenlerdi. Avrupa kaynaklarına göre, padişaha arizalarını sunmak üzere sırada bekleşen ahali, içinde bulunduğu kötü durumu ona ulaştırabilmek için başlarının üzerinde yanan ya da dumanı tüten keçeler tutarlar, böylece padişahın dikkatini üzerlerine çekmeye çalışırlardı.

Cuma selamlığının en önemli özelliği, padişahın halkın arasına karışması ve onların da istek ve şikâyetlerini doğrudan olmasa bile aracı bürokrasi vasıtasıyla padişaha iletebilmeleriydi. 1552-1556 yılları arasında Türkiye'ye bir ziyaret gerçekleştiren Manuel Serrano Y. Sanz'ın hatıralarında Cuma selamlığının bu fonksiyonunu: "Büyük Türk [Padişah] Cuma günleri camiye gider. Bu insanlar bir kamışın ucuna dilekçelerini bağlayarak Büyük Türk'ün geçtiği yol üzerinde beklerler. Büyük Senyör [Vezir] bu dilekçeyi alır, sarayda okur ve haksızlık görürse düzelttirir" (Sanz, 1979, s. 100) sözleriyle kaydetmişti. Bazı padişahlar, halktan toplanan arz-ı hâlleri bizzat okuyup gereğinin yapılması üzerine emir verebiliyordu. Örneğin, III. Mustafa'nın (1757-1774) cuma namazından çıktıktan sonra Valide Yalısı ve Eyyub Yalısı gibi çevre yalılara giderek burada kahve içtiği ve bu esnada da halktan kendisine ulaştırılan arzuhalleri okuyup bunların gereğinin yapılması yolunda direktifler verdiği bilinmektedir (Görür, 2018, s. 151). 


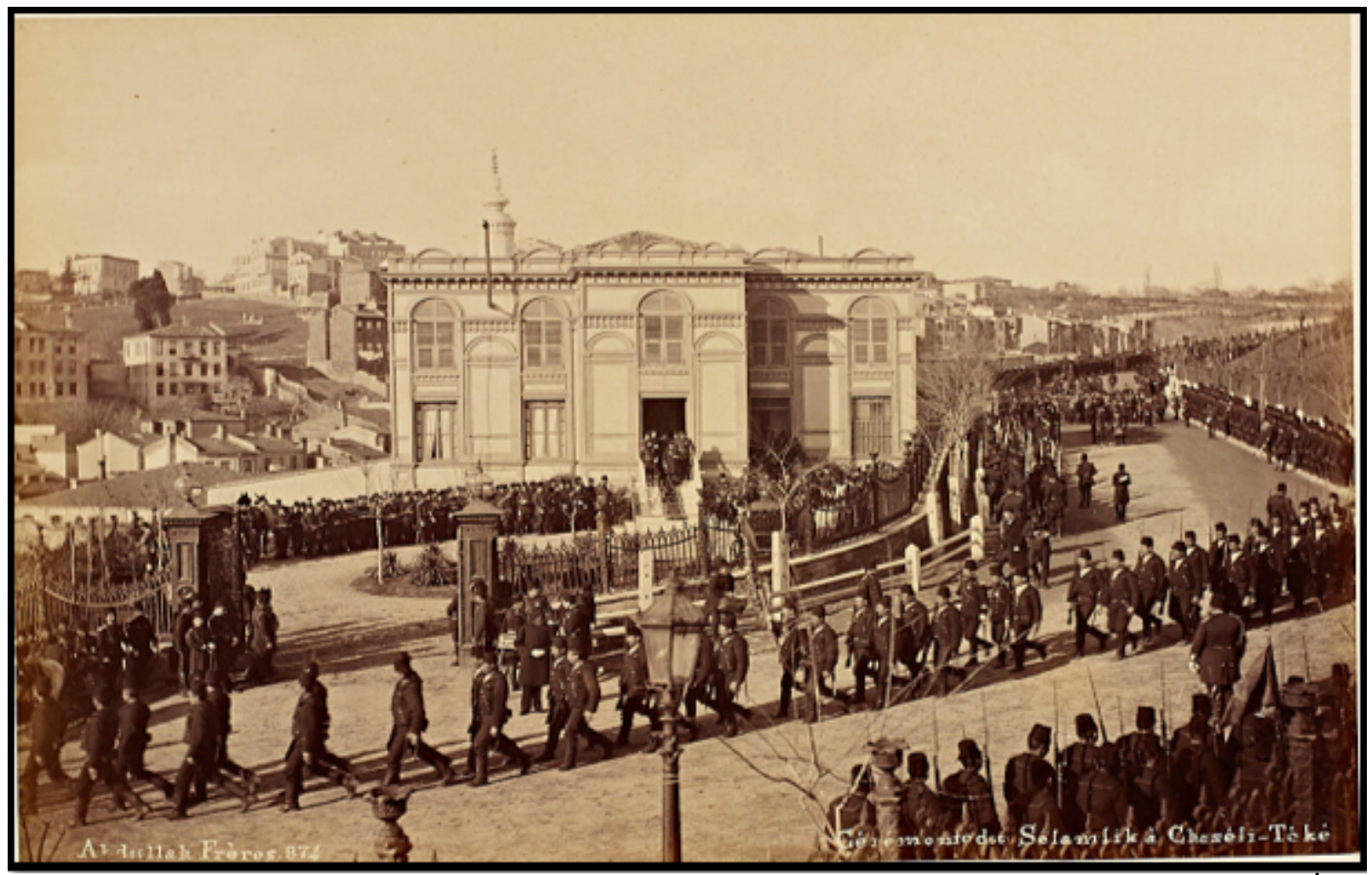

II. Abdülhamid döneminde Şazeli Tekkesi'nde düzenlenen bir cuma selamlığı sahnesi. Kaynak: İstanbul Üniversitesi, Nadir Eserler Kütüphanesi, II. Abdülhamid Han Fotoğraf Albümleri, yer no: NEKYA90817/10.

İngiliz ya da "Büyük" lakaplarıyla da tanınan Eğinli Said Paşa ise II. Abdülhamid döneminde düzenlenen cuma selamlıklarını çarpıcı bir dille şöyle nakleder:

“Cuma namazını kılmak icin halkın camiye girmesine bir şey denilmezse de Beşiktaş’tan Yıldız'a kadar gelebilmek epey zahmete ve birçok sorguya ve işkenceye katlanmaya mutevakkıftı. II. Abdulhamid'e suikast yapılacak diye sivil ve üniformalı yüzlerce zabıta memuru fırıl firıl halk arasında dolaşır onların ahvalini tecessüs ve tarassut ederlerdi. Bunların elinden kurtulup cami kapısına kadar gelenler de kapıdan girerken baştan ayağa kadar sıkıca muayene edilirler, üzerlerinde silah vesaire bulunmamasına son derece dikkat edilmekle beraber bilhassa padişaha verilmek üzere yazılmış arzuhal gorulurse o da silah ve bomba kadar tehlikeli sayılırdı. Bu türlü araştırmalara rağmen yine cemaat arasında birkaç kişi arzuhalini saklayabiliyor ve padişah camiye gelir gelmez avaz avaz bağırarak derdini dileğini söylüyor ve falan makamdan veya zâttan şikâyeti olduğunu söyleyerek çıkartıp arzuhalini gösteriyordu. O zaman saflar arasında dolaşan memurlar bu arzuhalleri alıp saraya götürürlerdi. Selamlık resmini seyir icin gelen halk uzaklarda duruyordu. Dürbün ve saire de kullanmak imkânı olmadığı icin padişahı görmek bunlara nasip olmazdı. Hele hac münasebetiyle Rusya'dan 
ve saireden gelenler buna muvaffak olmayı çok arzu ederlerse de göremeden giderlerdi. $\mathrm{Bu}$ türlü seyirciler civardaki ağaçlara tırmanırlar fakat polis ona da mani olurdu” (Ergin, 1977, s. 1057).

Cuma selamlığının ayırıcı yönü her hafta tekrar eden son derece politik bir ritüel olmasında aranmalıdır. Cuma selamlı̆̆ gibi iktidarın kurucu unsurlarından biri olarak yinelenen ritüellerin en çarpıcı tarafı, bir yandan geniş halk kitlelerinin sembolik bir dayanışma ruhu etrafında toplanmasına vesile olurken diğer yandan da bizatihi iktidarın kaynağını teşkil eden sembolik gücü pekiştirmesidir. Bu noktada Randall Collins'in izahatı aydınlatıcı olabilir. Ona göre (Kemper, 2011, s. 148), bireyler doğaları icabı şahsi statülerini maksimize etmeye odaklanırlar ve bunu da çevreyle etkileşim aracılığıyla gerçekleştirirler. Ritüel bir simbiyotik, karşılıklı odaklanma ve ortak mizaç meselesidir.

Collins'in önermesi açısından düşünüldüğünde, bir iktidar ritüeli olarak cuma selamlığının çift uçlu karakteri de kendiliğinden ortaya çıkar. Bu ritüel, mutlak iktidarı temsil eden padişahın şahsında devletle toplumun karşılıklı çıkarlarının tecessüm etmesinden başka bir şey değildir. Zira burada her iki taraf da çıkarlarını azami ölçüde artırmaya çalışmakta, padişah cuma selamlığı esnasında halka dağıttı̆̆g ihsanlar sayesinde geniş halk kitleleri üzerindeki otoritesini tahkim ederken halk da padişahtan alacağı ihsanlar ve ileteceği arz-1 hâller aracılığıyla kişisel emellerini gerçekleştirme şansı elde etmektedir. Aşağıdaki pasaj, Selim Deringil'in II. Abdülhamid döneminde İstanbul'da bulunan bir Japon bürokrat olan Yamada Torajiro'nun anılarından hareketle kurguladığı sahneyi yansıtmaktadır. Deringil' in başarılı betimlemesinin bizim için önemi, padişahın hem içte hem de dışta iktidarını ritüeller üzerinden yeniden kurgulamasında yatmaktadır.

“Yamada Torajiro konuklarını daima cuma selamlığına götürmeye özen gösterirdi. 1890’larda Japonların İstanbul'a gelmesi ender rastlanan bir durumdu ve Torajiro, kentin uzun dönemli tek Japon sakiniydi. Pırıl pırıl bir Mayıs sabahı, Yamada ve konukları, saraya doğru ilerleyerek yerini alan Arnavut Süvari Birliği'nin görünümü karşısında büyülenmişlerdi. Bando, Hamidiye Marşı'nı çalarken, güneş mızraklarını parıldatıyordu. Ardından gösterişli üniformaları içinde muhteşem Arap atlarına binmiş Hassa Alayı geldi. Son olarak, valide sultan ile kadın efendinin eşlik ettiği padişah at arabasıyla saraydan çıkarak camiye doğru ilerledi. Müezzin tiz sesiyle ezan okumaya başlayınca, padişah arabasından indi ve tüm birlikleri bir ağızdan haykırdı. Konuğu, Yamada' ya askerlerin ne dediklerini sorduğunda, şu yanıtı aldı: "Padişahım çok yaşa!" diye bağırıyorlar, tıpkı imparatorumuza "Tenno Heika Banzai!” diye tezahürat yaptı̆̆ımız gibi” (Deringil, 2014, s. 29). 
İktidar sıklıkla güçlülerin iradelerini güçsüzler üzerinde uygulamaları ve onları kendilerinin istemedikleri şeyleri yapmaktan alıkoymaları biçiminde kavramsallaştırılır. İktidar ayrıca güçlülerin sıkıca tutunduğu, güçsüzlerin de bunu onların elinden çekip almaya çabaladıkları bir tür iyelik olarak görülür (Mills, 2005, s. 34-35). Foucault'un düşüncesinde ise iktidar dolaşımda olan ya da ancak zincir şeklinde işleyen bir şey olarak analiz edilmelidir; iktidar hiçbir zaman şurada ya da burada yerleşmez, hiçbir zaman birilerinin elinde değildir, hiçbir zaman bir tür varlık ya da mal gibi temellük edilmez. İktidar işler, iktidar bir ağ biçiminde işler ve bu ağda bireyler yalnız dolaşıma girmekle kalmaz, aynı zamanda ona boyun eğmek ve onu uygulamak durumundadır. Bireyler hiçbir zaman iktidarın atıl ve onaylayıcı hedefleri değil, tam tersine her zaman iktidarın aracısıdır. İktidar bireyleri geçiş yolu olarak kullanır, bireylere uygulanmaz (Foucault, 2011, s. 107).

Bu bağlamda, cuma selamlığının etkileşime dayalı yapısı bize bu ritüelin aslında bir tür grup bilinci oluşturma süreci halini aldığını göstermektedir. Grup bilincinin yükselmesi ve grup kimliğinin pekişmesi, bireyi kimlik bunalımından kaynaklanan ve yabancılaşmayla sonuçlanan, anomi gibi, birtakım olumsuzluklara karşı korur. Ritüeller, toplumsal ilişkilerin düzenlenmesi, sürdürülmesi ve toplumsal düzenin sağlanmasında önemli işlevlere sahiptir (Karaman, 2010, s. 232) ki, cuma selamlığının politik işlevi de burada gün yüzüne çıkmaktadır.

\section{Sultan ve Foucault: II. Abdülhamid Döneminde Arz-ı Hâller ve “Güç Aşındırmaları"}

Foucault, devletin yekpare bir güç odağı biçiminde hareket ettiği görüşüne karşı çıkarak makro ölçekteki fenomenleri anlamlandırabilmenin ancak mikro ölçektekilerin önemini, yarattıkları etkiyi ve ilişkiselliği kavramakla mümkün olabileceğini öne sürer (Lynch, 2011, s. 23). Arz-1 hâlleri bu bağlamda ele aldığımızda, bu küçük ama anlamlı pusulaların temelde bir birey ya da grubun ihtiyaç duyduğu şeyi elde edebilmek için onu bağışlama gücünü elinde bulunduran bir kişiye hitaben kaleme alınan, hâlihazırda kurulmuş olan ya da bu metinle kurulması arzulanan bir diyaloğun ifadeleri olduğunu görürüz. Bu pusulalar, genelde toplumsal ve ekonomik açıdan üst konumda bulunan birine hitaben kaleme alınırlar ve müstedilerin durumuyla dileklerine ilişkin diğer bilgileri içerirlerdi (Houston, 2014, s. 24).

Dolayısıyla, arz-1 hâller iktidarla halk iradesinin kesiştiği kavşak noktalarında yer alan politik metinler, halk tarafından iktidarın mikrofizik evrenine uygulanmaya çabalanan güç aşındırmalarıdır. Arz-1 hâl uygulamasının evrimi bir bakıma aracısız ferdî politikaların kitle politikalarına dönüşmesinin öyküsüdür. Müste- 
dilerin gönüllülüŭgü esasıyla karakterize olan geçmiş dönemlerin politik geleneğindeki temel işlev yalnızca şikâyetlerin yetkililere ulaştırılmasından ibaret değildi. Arz-ı hâller aynı zamanda yakınmaların çözümlerine dair öneriler getiren, dahası, şikâyetin konusuna ilişkin yasa literatürüne katkıda bulunduğundan politik otoriteler tarafından son derece dikkatle yaklaşılan metinlerdi (Mark, 1998, s. 2154). Bu uygulama, kabul gördüğü yerlerde salt bireysel dileklere cevap veren bir kuruluşa dönüşmekle kalmayıp aynı zamanda konuya ilişkin mevzuatı da yönlendiriyordu (Van Voss, 2001, s. 3).

Arz-1 hâl mekanizmasının vurucu niteliği, bu yola başvuran kimselerin toplumsal pozisyonlarından bağımsız oluşuydu. Arz-1 hâller yüksek makamlarda bulunan kimselere gönderilebileceği gibi güç makamlarına yakın olanlardan yardım istemek amacıyla ve bunlara ulaştırılmak üzere gayrı resmî ya da kurumsal araçlar üzerinden de yollanabilirdi (Würgler, 2001, s. 16). Kaynaklarda rikā', ruk'a, mazhar, kâğıt ve son dönemlerde bazen arîza şeklinde de geçen arzuhal (arz-1 hâl), özellikle Osmanlılar'da en tabii bir hak olarak yaygın şekilde kullanılıyordu (İpşirli, 1991, s. 447).

Halil İnalcık’a göre (1988, s. 35), Osmanlı Devlet geleneğinin bir uzantısı olarak reâyâ ya da asker, zimmi ya da Müslüman olmaları fark etmeksizin halktan herkesin şikâyetlerini padişaha ulaştırmak amacıyla arz-ı hâl etme hakkı saklıydı. Ayrıca söz konusu arzın toplu biçimde veya bireysel düzeyde olması arasında da herhangi bir fark bulunmuyordu. Arz-1 hâl takdiminde gözetilen tek ayrım, arzı sunan kişinin ya da kişilerin resmi bir sıfata sahip olup olmamalarıydı ki, bu da yalnızca şikâyete verilen ismi etkiliyordu. Eğer padişaha pusula vermeye çalışan kişi askeri-resmi sınıfa mensupsa buna genelde 'arz denilirken reâyânın sunduklarına da 'arz-ı hâl deniliyordu.

Yukarıdaki sayfalarda da tartışıldığı gibi, Osmanlı Devlet, ulema sınıfi hariç tutulursa, devlet aygıtının işletilmesinde rol alan herkes kul statüsündeydi. Her ne kadar askeriye, kalemiye ve mülkiyede yer alan asker/memur sınıfi toplumsal statü açısından diğerlerine nazaran daha etkin bir pozisyonda bulunsalar da sonuçta bunlar da padişahın şahsına bağlı tebaayı temsil ediyorlardı. Bu perspektiften bakınca aslında 'arz ile 'arz-1 hâl arasında pek de büyük bir boşluk bulunmadığı kanaatine varılabilir. Yine de, aşağıda verilecek örnekler bir yandan genel olarak maruzatların politik iktidarın evrenindeki gücün aşındırılmasındaki payını ortaya koyarken diğer yandan da bunları padişaha ulaştıranların hukuki statülerinin belli belirsiz bir tesir kazanmasını kısmen açıklayacaktır.

Foucault'a göre, tabiyet mekanizmaları sömürü ve tahakküm mekanizmalarıyla olan ilişkileriyle birlikte düşünülürse anlamlandırılabilir. Fakat bunlar yalnızca diğer temel mekanizmaların uğrak noktası olmanın ötesinde onlarla karmaşık ve döngüsel bir ilişkinin temellerini atarlar (Foucault, 2001, s. 332). Foucault, bu argümanı destekleyecek nitelikte bir izahı 21 Kasım 1973 tarihli Collège de France dersinde 
şu şekilde yapar:

"Bana öyle geliyor ki, ortada birkaç asimetrik ilişki aracılığıyla egemen ve uyruğu birbirine bağlayan bir güç ilişkisi vardır: bir yandan bir vergi ya da kesenek bir tarafta yer alırken diğer tarafta da harcama yer alır. Egemenin ilişkisinde, egemen ürünler, hasatlar, el işi ürünler, silahlar, işgücü üzerine ve cesaret üzerine bir vergi getirir. Egemen, hizmetleri vergilendirmesiyle eşzamanlı işleyen asimetrik bir süreçte geri ödeme yapmaz çünkü egemen aldığını geri vermek zorunda değildir. Fakat egemenin doğum ve benzeri sevinçli olaylar için hediye vermek, ritüel seremonilerde yapılan harcamalar, koruma ya da Kilise tarafından sunulan dini hizmetler karşılığında taltif olarak verilenler gibi kendi tarhından farklı pek çok gideri vardır” (Foucault, 2006, s. 42).

Ekonomik bir ilişki biçimine vurgu yapıyormuş gibi görünse de, yukarıdaki pasajın iktidarın tesisi açısından hususi bir önemi olduğu aşikardır. Egemen gücün topluma bağışlamayı tercih ettiği zenginlik kaynağı yine toplumu oluşturan tebaanın cebinden çıkmaktadır. Yani egemenin iktidarını sürekli yeniden üretmek için kullandığı araçlar esasen iktidara tabi edilecek olanlardan elde edilen maddi gücün bir neticesidir. Öte yandan, egemen gücün iktidarını toplumsal uzamda sürekli yeniden kurgulaması ve pekiştirmesinde maddi kaynakların gücü yadsınamazsa da bunun sembolik bir tarafının olduğu da belirtilmelidir.

Bu bakımdan, Foucault'un tahakküm gücünü yeniden düşünmemiz için bağlamında bize iki alternatif sunduğunu hatırda tutarak arz-1 hâlleri değerlendirebiliriz. Ona göre, "tebaa” kelimesinin iki manası vardır. İlki, kontrol ve bağımlılık dolayısıyla bir başkasına tabiiyettir (Foucault, 1982, s. 781). Bu tabiiyet türünün açıkça ekonomik parametrelerin toplumsal dolaşımına göndermede bulunduğu ortadadır. Gücün oluşturulması, temerküzü ve bilinçli aşındırılması için iktidarın maddi fedakarlıklarda bulunması gerekir. Yukarıdaki pasajda verilen örnek de bunu göstermektedir. Diğer yandan, kendi bilincine ya da özüne ait bilgisi dolayımıyla kişinin kendi kimliğine duyduğu bağımlılık ayrı bir tabiiyet biçimi oluşturur (Foucault, 1982, s. 781). Her hâlükârda, bu iki anlam da tabi olmanın ve tabi kılmanın muhtelif yöntemlerini içerir.

Bu ayrım, gücün üretimi, aşındırılması ve tekrar üretimine içkin toplumsal görünüşlerle II. Abdülhamid döneminde cuma selamlıklarının taşıdığı anlam yüklü ritüelleri şaşırtıcı biçimde bir araya getirir. Zira burada aracı bürokrasi üzerinden padişaha, yani iktidarı hem maddi hem de lafzi açıdan temsil ettiği düşünülen güç kaynağına erişimi sağlayan çok basit ama eşzamanlı olarak bir o kadar da tesirli bir mekanizma vardır. Örneğin 1904 tarihli bir arşiv vesikası cuma selamlığında padişaha arz-ı hâl eden fakirlere 
edilen yardımdan söz etmektedir. Buna göre, selamlık esnasında padişahtan yardımını esirgememesini isteyenlere "sadaka-yı âfiyet-i cihankıymet-i hazret-i mülûkâne olmak üzere maruzat-1 rikâbiye idaresince" uygun görülen miktarlarda para dağıtılmıştır (B.O.A. (Başbakanlık Osmanlı Arşivi), Y..MTV., 1904, s. 261/22).

Burada dikkat çekici olan nokta, yapılan yardımın temel amacının padişahın sağlığı adına gerçekleştirilmiş olmasıdır. Halk kitlelerine topluca ya da bireysel düzeyde maddi yardımda bulunmak bir yönetici için iktidarını gündelik yaşantı içinde yeniden kurabileceği ve onu pekiştirebileceği mükerrer bir davranış biçimidir. Oysa Galeano'nun (2013, s. 59) son derece çarpıcı biçimde ifade ettiği gibi, hayırseverlik dikeydir, aşağılar. Dayanışma ise yataydır, yardım eder. İktidarın devamlılığı için elzem görülen bu pratik, sosyal devlet anlayışının hükümdarın şahsında dayanışmadan ziyade sadakaya dönüştüğünü gösterir. Sadaka, iktidarın salt padişahın yönetsel şahsında tecessüm ettiğini göstermekle kalmaz, aynı zamanda dini vecibeleri gözettiği imajıyla onun otoritesini bir kat daha pekiştirir.

Öte taraftan, sadaka ilişkisinin arz-1 hâllerin sonucu olarak iktidarın kısmi de olsa aşındırılması açısından bir önemi vardır. Zira sadaka vermenin toplum ve inanç bakımından kıymetine karşın sadakanın alıcılarına ulaştırılmasında birtakım problemler vardır. Bunların başında etiketlenme, aşağılanma, ayrımcılık ve adam kayırmacılık, tembellik ve ekonomik bağımlılık ile suiistimal edilme gibi son derece pejoratif kavramlar gelir (Taşçı, 2014, s. 90). Bu kavramların kullanımı ise Foucaultyen bağlamda yeni itaatkârlık şemaları oluşturur ki, bu yazı açısından düşünüldüğünde bağımlılık yaratıcı toplumsal şemaların en açık yansıması padişahın cuma selamlığı esnasındaki yardımları mukabilinde yönetim katına sunulan teşekkür arizalardır. Bunlardan birinde, bir grup asker tarafindan cuma selamlığında kendilerine yakınlık gösteren padişaha padişaha şöyle teşekkür edilmektedir:

"Ey şehinşâh-1 cihânsâhibe-i ilm sana çok teşekkür edelim. Mazhar-1 her-cümle-yi inâm-1 padişâhî ve pek mübin adilliği tebşîr edelim. Yevm-i cum'a resm-i konaklığında bize pürnefâsetinle kerem kılan mesrûr... hassa-yı şâhâne ser-çavuşlarından Abdullah Ragıb kulları ve silk-i mezkûr onbaşılarından Mustafa Lütfi ve silk-i mezkûr efrâdından Mehmeddin kullarının gün bugün...” (B.O.A., Y.PRK.AZJ., 1884, s. 9/90)

Arz-1 hâllerin toplu biçimde özetlerini aktaran hülasa defterleri, bu metinlerin iktidar-halk ilişkisini anlamak açısından büyük önemi vardır. Bunun da ötesinde, oldukça kısa, genelde birer cümle ile özetlenen bu arz-1 hâller iktidarın mikrofizik evreninde gücün nasıl temerküz ettiğini ve bununla aynı anda nasıl aşındırıldığını ortaya koyarlar. Zira arz-1 hâllerde belirtilen talepler kimi zaman basit meselelerden ve 
bunların hallinden fazlasına işaret ederler. İktidarın temerküzüyle aşındırılmasının aynı anda gerçekleşmesi ironik dursa da söz konusu metinlerden verilecek örnekler konuyu aydınlatacaktır. Ayrıca belirtmek gerekir ki, arz-ı hâller padişahın otoritesinden gerek maddi gerekse manevi pay kapmaya çalışanların cinsiyetleriyle toplumsal konumlarını anlamak açısından da son derece önemlidir.

II. Abdülhamid'in henüz çiçeği burnunda bir padişah olarak tahta çıktığı yıldan, 1876'dan birkaç örnek verelim. 12 Aralık 1876 tarihinde rikâb-1 hümayuna arz edilen pusulalarda dikkati çeken başlıca husus, ricacıların mülk ve para edinme istekleridir. Mesela saraylı Hüsne Gül Hanım saraydan kendisine mahsus olacak şekilde bağlanmış olan maaşının kesildiğini, maaşının eskisi gibi düzenli biçimde ödenmesini rica ederken Asâkir-i Şahane'den İsmail Çavuşun hanımı Emine Hatun da "bîmekân olduğundan bir hâne ihsan buyurulmasını istirhâm” etmektedir. Üçüncü bir kadın, Aişe Şefika Hatun ise yukarıdaki iki isteği birleştirir ve kendisine hem ev verilmesini hem de maaş bağlanmasını talep eder. Kırım muhacirlerinden Ümmü Gülsüm Hatun ise iki çocuğunun bir mektebe yerleştirilmesini arzulamaktadır. Ayrıca kayıtların bir tür şikâyet mekanizması olarak işledikleri de görülür. Diğer deyişle, adaleti aracısız biçimde doğrudan iktidarın membaından almak isteyenlerin de sık sık arz-ı hâl ederlerdi. Aynı belgede, yukarıda anılanların haricinde Zenciye Hace Âlim Hatun'un isteği bu türden bir başvuruyu yansıtmaktadır. Hace Âlim Hatun sahibi olduğu haneyi kendisine bakmak koşuluyla Halıcı Mehmed'e vermiştir. Fakat Mehmed kadına bakmadığı gibi üstüne bir de onu dövmüştür. Hal böyle olunca, Hace Âlim Hatun da derdini en hızlı ve kesin surette çözülmesi için doğrudan padişaha açmaya karar vermiştir (B.O.A., İ.DH., 1876, s. $736 / 60300)^{2}$.

Arz-1 hâllerin içeriğine göz atıldı̆̆ında bu pusulaların yalnızca erkek nüfusça değil kadınlar tarafından da sunulduğu gözden kaçmamaktadır. Tabi arz-ı hâller tamamen maddi yardım talebinde bulunmak üzere kaleme alınmıyordu. Mesela 1906 yılında verilen bir arz-ı hâlde, Sıdıka adlı bir kadın hapishanedeki oğlunun padişah tarafından affedilmesini talep etmişti. Sıdıka, İzmit sancağı bidayet mahkemesince davası görülen ve İstanbul Hapishane-i Umumisinde on beş sene kürek cezasına çarptırılan Mazhar adlı oğlunun affedilmesini hastalığı yüzünden talep etmişti. Bunun üzerine, Mazhar Bâb-1 Zaptiye Etıbba Dairesi tarafından sağlık muayenesinden geçirilerek yirmi beş yaşlarında olduğu ve gerçekten de sağlığının yerinde olmadığı anlaşılmıştı. Sonuçta padişahın emriyle "bakiye müddet-i cezaiyesinden dolayı sadaka-yı afiyet-i cihân-kıymet-i hazret-i padişahî olmak üzere” salıverilmiştir (B.O.A., İ.AZN., 1906, s. 67-26).

\footnotetext{
${ }^{2}$ Cuma selamlıklarının iktidar-halk ilişkisinin imgesel tesisinde oynadığı rolün yanı sıra iktidarı devirmeye yönelik birtakım girişimlere de açık olduğu ayrıca belirtilmelidir. Bu çalışmanın aydınlatmayı amaçladığı meselenin sınırlarının dışında kalmakla beraber, 1905 yılında Ermeni komitacıları tarafından Cuma Selamlığına çıkan II. Abdülhamid'e yönelik başarısızlıkla neticelenen suikastı da hatırda tutmak gerekir (y.n.).
} 


\section{Sonuç}

Kimi diplomatik belgelerde "Allah'ın yeryüzündeki gölgesi” olarak lanse edilen Osmanlı padişahının yönetme erkini de aynı kadir-i mutlak güçten aldığına inanılıyordu. Böylece iktidarının temellerini maddi gücün yanına psikolojik bir etken daha koyarak pekiştiren padişah bu iki unsurlar girift bir görünüm arz eden muhtelif gündelik ritüeller aracılığıyla da sürekli yeniden kurmayı hedefliyordu. Bu bağlamda, cuma selamlığı olgusuna birkaç anlam birden atfedilebilir. Bunlardan ilki, her sıradan Müslüman gibi padişahın da dini vecibelerini halkın arasına karışarak, yani aslında kendisinin de sıradan bir vatandaş olduğunu tebasına hatırlatarak yerine getirmesiydi.

İkincisi, padişahın cuma selamlığına gidişinin politik bir sembol olmasıydı. Üçüncüsü de bu gidiş dönüşün bir tür seremoni, hatta kemikleşmiş bir ritüele dönüştürülmesiydi. Padişahın saraydan çıkarak kendini geniş halk kitlelerine görünür kılması, reayanın tahayyülündeki baskın önder portresini tahkim ederken bunun her hafta tekrarlanması da padişahın otoritesini pekiştirmeye yarıyordu. Bunun bir kanıtı da padişahların sürekli aynı camiye gitmeyerek farklı yörelerdeki halkın huzuruna çıkmayı tercih etmeleriydi.

Öte yandan, cuma selamlıklarının gelenekselleşmiş bir uygulaması olarak askeri bir geçit töreni biçiminde düzenlenmesi de çarpıcıdır. Burada bilhassa atlı süvarilerin önemli bir rol oynadı̆̆ı dikkatten kaçmaz. Böylece bir yandan padişahın güvenliğini temin ediliyor, diğer yandan da bu ritüel bir tür gövde gösterisine dönüştürülüyordu. Otoritenin tesisinde önemli bir rol üstlenen imaj ve etki faktörü burada devreye giriyor, cuma selamlığı sayesinde padişah hem halkın kendisine yüz yüzeyken verdiği reaksiyonu ölçebiliyor hem de sembolik gücünü askeri gösteri üzerinden tecessüm ettiriyordu.

Arz-1 hâller ise başlı başına birer güç kaynağıydı. Çünkü nihai başvuru mercii olan padişahtan başkası halkın sorununu çözmeye muktedir değildi. Bir şikâyet, rica ya da yardım talebiyle padişaha gitmek, mesele her ne ise onu kökten çözüme kavuşturmak anlamına geliyordu. Arz-1 hâller, içeriklerinin ne olduğu fark etmeksizin, padişaha lütufta bulunma firsatı tanıyan açık birer güç sembolüydü. Arz-1 hâl uygulamasının toplumsal işlevinin yanı sıra politik açıdan halk-iktidar ilişkilerini çözümlemede de son derece yararlı bir uygulama olduğu ortadadır.

Güç ilişkilerinin dengelenmesi bağlamında düşünülürse, arz-1 hâlleri bir tür kazan-kazan ilişkisine benzetmek mümkündür. Padişaha ulaştırılan arzların ve bunlara yönetim katından verilen cevapların sonuçları konusunda fikir yürütmek için elimizde yeterince delil olmamakla birlikte, padişahın bu isteklerden astronomik olmayanları ayıklayarak bunlara olumlu cevap verdiğini düşünmemek için bir neden 
yoktur.

Son tahlilde, arz-1 hâllerin her iki tarafin da kazançlı çıktığı bir mekanizma olduğunu görürüz. Arz-1 hâl uygulamasının padişah açısından ehemmiyeti, sadaka vermek usulüyle küçük çaplı bir meta dolaşımını başlatarak halkı emperyal zenginliğine ortak etmesinde aranmalıdır. Buna ilaveten, halkın istek ve şikâyetlerini arz etmek üzere cuma selamlığını beklemesi ve namaz öncesiyle sonrasının bir nevi geçit resmine dönüşmesinin sultani gücün konsolidasyonunda hatırı sayılır bir etkisi olduğu açıktır. Politik gücün kurulmasında rol oynayan diğer unsurlar cari tutulmak kaydıyla, arz-1 hâllerin, iktidarın bekasını temine çalışan bürokratik ve askeri sınıf görevlilerine ek olarak sıradan halk için de iktidarın maddi ve manevi gücünü bir yandan aşındıran, diğer yandan da onun gündelik ritüeller üzerinden kendini mütemadiyen üretmesine katk1 sunan pusulalar olduğu söylenebilir.

\section{Kaynaklar}

Akçakaya, M. (2016). Weber'in bürokrasi kuramının bugünü ve geleceği, Gazi Üniversitesi Sosyal Bilimler Dergisi, 3 (8), 275-295.

Akyıldız, A. (2018). Osmanlı Bürokrasisi ve Modernleşme. İstanbul: İletişim Yayınları.

Alikılıç, D. (2004). Imparatorluk seremonisi: Osmanlı'da devlet protokolü ve törenler. İstanbul: Tarih Düşünce Kitapları.

Aslan, S. ve YILMAZ, A. (2001). Tanzimat döneminde osmanlı bürokratik yapı ve düşüncesinin değişimi, Cumhuriyet Üniversitesi İktisadi ve İdari Bilimler Fakültesi Dergisi, 2 (1), 287-297.

Aykurt, Ç. (2001). Padişah-halk buluşmasını temin eden törenlerden birisi: Cuma selâmlı̆̆ı, Tarih Incelemeleri Dergisi. 16 (1), 201-204.

B.O.A. (Başbakanlık Osmanlı Arşivi), I.DH., 736/60300, 25 Zilkade 1293 (12 Aralık 1876).

B.O.A., Y..MTV., 261/22, 5 Rebiülahir 1322 (19 Haziran 1904).

B.O.A., Y.PRK.AZJ., 9/90, 29 Zilhicce 1301 (20 Ekim 1884).

B.O.A., I.AZN., 67/26, 3 Cemaziyelahir 1324 (25 Temmuz 1906).

Berkes, N. (1964). The development of secularism in Turkey. Londra: Hurst \& Company.

Çaha, Ö. (1994). Osmanlı'da sivil toplum. Ankara Üniversitesi SBF Dergisi. 49 (2),79-99. 
Demirel, F. (2019). Sultan II. Abdülhamid'in kamusal alanda görünürlüğü. Sultan II. Abdülhamid Dönemi: Siyaset - iktisat - dış politika - kültür - eğitim. M. Bulut, M. Enes Kala, N. Salık ve M. Nar (Ed.). İstanbul: İZ̈̈ Yayınları, 95-111.

Deringil, S. (2014). İktidarın sembolleri ve ideoloji: II. Abdülhamid Dönemi (1876-1909). İstanbul: Doğan Kitap.

Ergin, Osman N. (1977). Türkiye maarif tarihi, 3 (4). İstanbul: Eser Matbaas1.

Foucault, M. (1978). The History of Sexuality - Volume I: An Introduction, R. Hurley (Çev.). New York: Pantheon Books.

Foucault, M. (1982). The subject and power. Critical Inquiry. 8 (4), 777-795.

Foucault, M. (2001). The essential works of Foucault 1954-1984. J. D. Faubion (Ed.). 3. New York: The New Press.

Foucault, M. (2006). Psychiatric power: Lectures at the Collège de France, 1973-74. F. Ewald ve A. Fontana (Ed.). G. Burchell (Çev.). Londra: Palgrave Macmillan.

Foucault, M. (2011). Entelektüelin siyasi işlevi - seçme yazılar I, I. Ergüden, O. Akınhay ve F. Keskin (Çev.). İstanbul: Ayrıntı Yayınları.

Foucault, M. (2013). Güvenlik, toprak, nüfus: Collège de France dersleri, 1977-1978. F. Taylan (Çev). İstanbul: İstanbul Bilgi Üniversitesi Yayınları.

Galeano, E. Biz hayır diyoruz. B. Kale (Çev.). İstanbul: Metis Yayınları.

Gölbaşı, Ş. (2015). Güvenlik, toprak, nüfus. Mülkiye Dergisi. 39 (2), 327-340.

Görür, C. (2018). Sultan III. Mustafa’nın Cuma selâmlıkları, History Studies, 10 (9). 147-155.

Heyd, U. (1973). Studies in old ottoman criminal law. Oxford: Clarendon Press.

Houston, R. A., (2014). Peasant petitions: social relations and economic life on landed estates, 1600-1850. New York: Palgrave Macmillan.

İnalcık, H. (1988). Şikâyet hakkı: 'arz-1 hâl ve 'arz-1 mazharlar. Osmanlı Araştırmaları, VII-VIII, 33-54. İnalcık, H. (2019). Osmanlı fetih yöntemleri. Söğ̈̈t’ten İstanbul'a: Osmanlı Devleti'nin kuruluşu üzerine tartısmalar. O. Özel ve M. Öz (Der.). Ankara: İmge Kitabevi. 443-472. 
İpşirli, M. (1991). Arzuhal. TDV İslam Ansiklopedisi. 3, s. 447-448.

İpşirli, M. (1991). Osmanlılarda Cuma Selâmlı̆̆ı (halk hükümdar münâsebetleri açısından önemi), Prof. Dr. Bekir Kütükŏ̆lu’na armă̆an. İstanbul: Edebiyat Fakültesi Basımevi, 459-471.

İstanbul Üniversitesi, Nadir Eserler Kütüphanesi, II. Abdülhamid Han Foto ğraf Albümleri, yer no: NEKYA90817/10.

Karaman, K. (2010). Ritüellerin toplumsal etkileri, SDÜ Fen Edebiyat Fakültesi Sosyal Bilimler Dergisi, $21,227-236$.

Kemper, Theodore D. (2011). Status, power and ritual interaction: a relational reading of Durkheim, Goffman and Collins. Surrey: Ashgate.

Lynch, Richard A. (2011). Foucault's theory of power, Michel Foucault: Key Concepts. D. Taylor (Ed.). Durham: Acumen Publishing.

Mardin, Ş. (1991). Türkiye'de toplum ve siyaset - makaleler 1. M. Türköne ve T. Önder (Der.). İstanbul: İletişim Yayınları.

Mark, Gregory A. (1998). The vestigial constitution: the history and significance of the right to petition. Fordham Law Review, 66 (6), 2153-2231.

Mills, S. (2005). Michel Foucault. New York: Routledge.

Patton, P. (1994). Foucault's subject of power. Political Theory Newsletter. 6 (1), 60-71.

Sakaoğlu, N. (1995). Cuma Selâmlı̆̆g, Skylife, 112.

Sanz, Manuel Serrano Y. (1979). Türkiye'nin Dört Yılı, 1552-1556. A. Kurutluoğlu (Çev.). İstanbul: Kervan Kitapçılık.

Taşç1, F. (2014). A psycho-social solution to problems related to social assistance recipients: 'sadaqa stones modeling'. İstanbul Üniversitesi İktisat Fakültesi Mecmuası, 64 (2), 89-108.

Van voss, Lex H. (2001). Introduction. Petitions in Social History, L. Heerma van Voss (Ed.). Cambridge: Press Syndicate of the University of Cambridge, 1-10.

Würgler, A. (2001). Voices from among the "silent masses": Humble petitions and social conflicts in early modern central europe, Petitions in Social History. L. Heerma van Voss (Ed.). Cambridge: Press Syndicate of the University of Cambridge, 11-35. 


\section{Makale Bilgi Formu}

Yazar(lar)ın Katkıları: Makale tek yazarlıdır.

Çıkar Çatışması Bildirimi: Yazar tarafından potansiyel çıkar çatışması bildirilmemiştir.

Destek/Destekleyen Kuruluşlar: Bu araştırma için herhangi bir kamu kuruluşundan, özel veya kâr amacı gütmeyen sektörlerden hibe alınmamıştır.

Etik Onay ve Katılımcı Rızası: Çalışmanın etik kurul belgesine ihtiyacı olmadığı yazar tarafından belirtilmiştir.

Bu çalışmanın yazım sürecinde bilimsel, etik ve alıntı kurallarına uyulmuş; toplanan veriler üzerinde herhangi bir tahrifat yapılmamış, karşılaşılacak tüm etik ihlallerde “Universal Jounal of History and Culture" hiçbir sorumluluğu olmayıp, tüm sorumluluk yazara aittir. 